\title{
Running Unopposed: Assessing the Impact of Term Limits on Competition in Florida and Maine
}

\author{
ERIC PRIER \\ Florida Atlantic University \\ KEVIN WAGNER \\ Florida Atlantic University
}

This research explores the implications of the adoption of term limits on elected officials in Florida. After exploring the historic assumptions and motivations behind the term-limits movement, we test the assumption that term limits produce more competition for elective office. Using election data provided by the state of Florida, a multipronged examination is conducted to assess the consequences for legislative competition, as the implementation of term limits in the state. A comparison is also made to Maine, which was an early adopter of term limits. This research finds that competition has not increased. In fact, it has generally declined, and often sharply. The findings suggest that potential candidates, while influenced by local or national trends, wait for guaranteed open seats rather than challenge incumbents. Finally, alternative reasons for the decline in competition and the likely results of the long-term use of term limits on the political system are explored.

Term limits in Florida began as part of a national trend based on frustration with the perceived lack of responsiveness of elected bodies to the will of the public. Floridians, along with other states, such as California, Colorado, and Oklahoma, interjected themselves into the institutional rule structure of the state by using the power of a ballot initiative to change the terms of service of elected officials from the state. The underlying logic of the approach was based on foundational democratic notions grounded in historic progressive thinking (Mayton 1999). Negative views of elected officials, combined with a concerted effort by the Republican Party to overcome its minority status on both the

Acknowledgements: We would like to thank the anonymous reviewers for their helpful comments and suggestions. The order in which the authors are listed was determined by a coin flip. 
national and in various state legislatures, gave momentum to term-limit proposals (Peery 1999). Popular ballot measures and term limits were perceived as a means to bypass the buffering effect of the legislative bodies in the states in order to defeat the dominance of special interest groups in the law-making bodies.

The support for such an approach in Florida is not surprising. Florida has a long and unfortunate record of creating legal and procedural barriers that obstruct representation by allocating districts in a way that would allow a minority of voters to elect controlling majorities in both houses of the state legislature (Prier 2003). In 1960, the legislative districts were so malapportioned that a majority of state legislators were elected by less than 13 percent of the state's population (Dauer 1984, 141). Hugh Douglas Price (1962, 81) called it "the state with the least representative legislature of any in the Union ... Florida stands alone in both House and Senate [in that] the ratio of largest to smallest population per member is on the order of 100-to-1."

The political cleavage in Florida was largely geographic and favored the rural north. The grip of the northern legislators, often referred to as Porkchoppers, was not broken until judicial intervention into districting by the courts. The matter was settled for all states in the landmark cases of Baker v. Carr (1962) and Reynolds v. Sims (1964). The U.S. Supreme Court mandated the "one man, one vote" standard for legislative districting, holding that each individual had to be weighted equally in legislative apportionment. This forced the state of Florida to recognize the growth of newer urban areas, including Miami, Jacksonville, and Tampa, and to redistrict accordingly.

While the districting issue was put to rest, the dissatisfaction with the composition of the legislature was not settled. Although the geographic imbalance was largely addressed, the power of long-sitting legislators to redirect funds and policy in favor of their districts was not. Concern over the power of entrenched incumbents appears to be a significant motivating factor for term limits in Florida, as well as in other states (Doron and Harris 2001). Nonetheless, it is worth noting that some term-limit initiatives were not successfully adopted by the voters. For instance, the state of Washington rejected term limits in 1991 despite the success of other state measures (Olson 1992).

The battle over term limits in Florida became a more modern attempt to address the influence of longtime legislators by forcing them from the legislature. The actual movement for term limits in Florida was the product of a popular initiative campaign to amend the state constitution to limit legislators to eight years in office. The slogan it used was "Eight is Enough." The proposed initiative tapped into citizens' frustrations with well-settled incumbent legislators elected in both the state and federal government.

While the campaign was viewed largely as being grassroots, it was led by republican supporter Phil Handy and was financed by an interest group named "Americans Back in Charge" (Depalo 2006; Rausch 1996). Although the 
benefits of the term limits would inure, at least initially, to the minority Republicans, the support for the measure was broad and it crossed party lines. ${ }^{1}$ Despite judicial challenges, the ballot initiative was allowed to go to the voters by the Florida Supreme Court. In 1992, it was overwhelmingly approved with a remarkable 76.8 percent in favor of the measure, giving Florida the largest margin of victory among the states that have approved term limitations (National Conference of State Legislatures 2006).

\section{Approaches to Term Limits}

There are many aspects of the implementation of term limits that have generated research, such as focusing on the implications of the movement toward more popular intervention in the process of governing (Wagner 2005), and on the implications for the governing structure and balance of power among state institutions where legislators lack institutional experience when facing the governor or well-settled interest groups (Cain and Levin 1999; Carey, Niemi, and Powell 1998; Rosenthal 1992). Despite claims that new citizen legislators will be less beholden to interest groups (Will 1992), the research increasingly indicates that these novice legislators are increasingly dependent on others - such as interest groups - for the knowledge and experience necessary to understand the legislative process (Cain and Levin 1999; Capell 1996; Moncrief and Thompson 2001).

Much of the research has focused on the measurable results of term limits on the makeup of legislatures. The incumbency advantage, especially in the area of fund raising, is often a significant bar to office (Cain and Levin 1999; Will 1992). Initially, there was a belief that term limits would generate greater diversity in legislatures by removing the incumbency advantage and opening up seats in the legislature to women and minorities that might otherwise continue to be unattainable because of the incumbency advantage (Boeckelman 1993; MacManus 1994; Thompson and Moncrief 1993). Although it was strongly advocated that term limits would recreate the idealized vision of the state legislature as a citizen body focused back on people instead of interest (Fund 1992; Mitchell 1991; Will 1992), early studies have not shown a significant increase in the numbers of women or minorities (Bernstein and Chadha 2003; Caress 1999). Initial studies in Florida are consistent with these findings and show no significant increases in minority or women in the state legislature (Depalo 2006; Phelps 2002; Schraufnagel and Halperin 2006; Wagner and Prier 2008).

\footnotetext{
${ }^{1}$ Though initially the organizational support for term limits appeared ideological or at least partisan, this support seems to be less evident today. Handy himself is now making use of a technical maneuver to extend his stay as an appointed state official beyond the eight years that would otherwise bound his term (Date 2006).
} 
Further, assertions that term limits might change the character of legislators also appear to be unfounded. Supporters of term limits regularly argue for more part-time citizen legislators, and states like Florida maintain a part-time legislature based on the belief that regular citizens should participate in state government (National Conference of State Legislatures 2005; Wagner and Prier 2008). Nonetheless, although there is little evidence that candidates in the post-term-limits era are significantly different in Florida, studies indicate that candidates for office are motivated by political ambition (Powell 2003). Meanwhile, scholars have theorized that term limits force candidates to rotate out of legislative positions, but do not drive them out of public service or out of politics in some form, such as lobbying (Farmer, Rausch, and Green 2003; Rausch 1998). This trend is illustrated in Florida, where a former state senate minority leader (Lois Frankel), after being term-limited out of the state legislature, simply switched to local politics and became mayor of West Palm Beach. Indeed, this makes sense for politicians who increasingly retain offices through incumbency advantages, who are more professionalized, and who view their elected jobs as an occupation unto itself. That is why studies in this area are incomplete. It is increasingly apparent that term limits lead to a political game of musical chairs.

\section{A Theory of Term Limits and Competition}

Despite the results above, it is in the area of competitiveness that term limits may have their most enduring effect, and in the direction opposite initial expectations. Term limits were intended to increase competitiveness by removing incumbents and forcing more open seats. Term limits should result in an increase in competition because of a larger pool of experienced candidates that would become regularly available (Fett and Ponder 1993), and while early research has supported this supposition, there has been a measured increase in the turnover rate of legislators in states that have enacted term limits. In 15 states where term limits have been enacted, there has been an almost universal replacement of the membership of the legislatures (Bowser, Chi, and Little 2006). Admittedly, without addressing the way politicians may respond and adapt to term limits, as a practical matter, the effect of such limits are plain on their face, because at least one thousand legislators have been barred by law from seeking reelection to their state legislature (Kurtz, Cain, and Niemi 2007).

Further, there has been some evidence that term limits generate greater electoral competition in part by generating larger numbers of available politicians to compete for higher office (Francis and Kenny 1997; Powell 2000). Nonetheless, some research has suggested that legislatures with term limits may actually result in less competition for incumbent seats at the state level (Carey, Niemi, and Powell 2000). In reviewing the effects of term limits in Michigan, Sarbaugh-Thompson and others (2004) noted that incumbents in this state face less competition in their last year in office, and maintained a strong incumbency 
advantage. Research on the first years of Florida's implementation of term limits has also concluded that competition, at least initially, has not increased, and has actually decreased (Schraufnagel and Halperin 2006). However, this research and analysis is early in the term-limits era, and does not present a comprehensive approach to understanding the implications of term limits as a broader pattern.

To do this, we suggest a broader understanding of the role of term limits using the examples of Florida and Maine. The effects of term limits are likely to differ to some degree with the individual politics and institutional hurdles in each state. Nonetheless, the specific case of Florida presents an important window into the literature on the effects of term limits and electoral competition. As of 2008, Florida is geographically large and the fourth most populous state, and it has maintained term limits through several election cycles. Florida presents a strong case for the study of the implications of term limits on political representation. The state tends to favor Democratic registration, and it is almost evenly divided and particularly diverse (Carsey and Nelson 2008; Parker and Towner 2008). It is a state that should be competitive and often is at the national level, with two U.S. senators from different parties. However, it is not very competitive at the state level (especially in the legislature), which presents a particularly strong test case to observe if the application of term limits can create the competitive environment that proponents anticipated.

We assess the fundamental proposition that the resulting elections have become more competitive in the state of Florida since the adoption of term limits. Specifically, the proposition from term-limits supporters, that state legislative races would become more competitive and draw more qualified candidates, is evaluated. Beyond this test, we consider the application of leading theories to explain increases or declines in electoral competition and we present a theoretical construct to focus and forecast how term limits will structure and affect electoral competition in future electoral races. Finally, we compare Florida's experience with term limits to another early adopter of term limits, the state of Maine.

We begin with the premise that candidates are rational actors seeking to maximize their chances of winning a seat and minimizing the potential costs and risks (Bianco 1984; Jacobson and Kernell 1983; Osborne and Slivinski 1996). Running for office is an increasingly expensive endeavor, even when running for state rather than federal office. Costs range from registration fees to advertising and campaign staffing. While favored and important elected positions attract numerous candidates willing to vie for the office, the likelihood of extensive risk taking for low-paying state legislative seats should be fairly low. In short, candidates need to believe they can - and probably will - win in order to bear the costs of running. More directly, when the likelihood of winning a seat is greater than the likelihood of losing, then a potential candidate will often choose to expend the resources and run for office (Feddersen, Sened, and Wright 1990). 
Obviously this rational-actor approach supports the basic proposition of term-limit proponents who argue that the presence of an incumbent is a disincentive for a possible challenger. Thus it is largely an electoral truism that open seats will draw more quality candidates (Bianco 1984), often because the unidirectional dissemination of pleasing information from legislators makes it likely that many voters do not know enough about other candidates to feel comfortable casting a ballot for challengers (Cox 1996; Mann and Wolfinger 1980). This latter point is important, because the decline in competition for legislative seats may be linked to a decline in political information concerning challengers; information that may be necessary for voters to make informed choices about candidates (Delli Carpini and Keeter 1996). Consequently, the use of term limits will regularly remove incumbents and signal to potential candidates periods of reduced risks, with the end result being increasing competition.

This is likely to have a very stark effect on lower-level elections where information, especially information about challengers, is scarce. Where there is no well-funded and experienced incumbent to defeat for the seat, candidates will, and do, run. The forced removal of sitting legislators should create more opportunities for potential candidates by lowering the entry cost in predictable ways. The long-term effect would be to regularly retire the leadership of each chamber and create expected open seats to cyclically draw candidates, with the distinct likelihood of moving deep enough into the potential pool to reach a greater number of nontraditional candidates.

Unfortunately, these assumptions are not the only way to view the implications of limited terms. We suggest an alternative hypothesis that term limits will influence rational actors to challenge for office in predicable patterns. As noted earlier, rational candidates will wait for an open seat to maximize their opportunity to be successful. In the absence of term limits, the availability of open seats is unpredictable, forcing candidates to weigh the risk of waiting indefinitely against the costs of running against an incumbent. Term limits change that dynamic, as open seats are guaranteed at least every eight years in both Florida and Maine. This should create patterns of noncompetition by encouraging possible challengers to wait for open seats instead of challenging incumbents, creating periods of reduced electoral competition bounded by the expiring terms.

Often, local and sometimes national conditions create some variance in competition between elections. Because candidates are rational actors, the general pattern should be reduced competition, at least over the length of the limited legislative term. The end result of term limits in Florida would be the creation of an artificial eight-year term for incumbents, with little incentive to be concerned about aggregate public opinion or voters during the length of this term. If this pattern holds true, then there should be a marked drop in competition in the election years during the eight-year limited terms. That would be evidenced in Florida elections from 1996 through 2006, with the 
competitive elections returning in 2008 when the surviving members of the current crop of legislators are forced from office. The end result is that term limits may now protect incumbents to a higher degree than before the measure was enacted.

\section{Methods}

Term limits are gathering increasing scrutiny, and for good reason. According to the National Conference of State Legislatures (2008a,b), the impact of term limits has been significant and in recent years, they have resulted in dozens of key state legislative leaders and hundreds of important standing committee chairs being removed from office. The consequences of these changes in the operation of legislative bodies is important and well-studied (Cain and Levin 1999; Carey, Niemi, and Powell 1998). However, we do not focus on these changes. Instead, we are interested in empirically assessing the impact of term limits on the nature of the electoral competition for seats, and more directly, the number of challengers for those seats.

As a result of the research question, this study differs from earlier work in several respects, beginning with the nature of the data analysis. The preponderance of studies on term limits is restricted to a single state and tends to focus on turnover or electoral margins when measuring competition. The current analysis examines district competition in terms of the numbers of intraparty and interparty challengers for each seat. Although this has been done for a single state legislative chamber (Prier 2003), this approach is largely unseen in the literature, especially when used in a comparative perspective.

Part of the difficulty with this approach is the nature of electoral data. Although there are very good and thorough state elections data available, such as Carsey and others (2003), much of the data were not complete enough to use for the purposes intended here. Although the Florida data in Carsey and others (2003) conforms with the records of the Florida Secretary of State, the nature of the electoral system and state reporting requirements make it difficult to map the individual races to the final ballot outcomes at the party and legislative chamber levels. This occurs because Florida does not require the candidates to gain votes for all legislative seats, and to thus appear on the ballot. Although inquiries do not lead to conclusive answers as to why this is so, it is probably because the state presumes that those candidates who run unopposed for a seat would vote for themselves and thus would win each of their unchallenged elections.

The consequence of this manner of recordation is that reported results (and the resulting digitized data) do not include those races in which unchallenged candidates are "elected" with no votes. This means that the data is incomplete if one wants to assess the degree to which legislators are subject to challengers. To overcome these obstacles, we mapped the candidates to their respective seats, from primary through general election to being named the winner of the 
seat. The methodology employed here provides an overview of the actual legislative challenger pool that empirically faces the electorate in Florida and Maine. In effectuating this approach, we applied some basic rules. The definition of challengers included all write-in votes and third-party candidates who may have garnered any votes, even if it was merely a single ballot. This was done in order to give the most liberal estimate of the robustness of competition in the primary and general elections. The estimates provided herein are the best case that can be made for competitive legislative elections in these two states, and if one were to discount the numerous write-ins or "other" votes that generally appear in the single digits throughout these states' elections, then the competitive pool and their scores would decline.

Although it is beyond the scope of this study, it is noteworthy that a good number of primaries (and their general elections) were not challenged, and indeed, there were numerous party primary districts that had no candidate whatsoever from the major parties. In fact in Maine, where all candidates, whether opposed or not, must be on the ballot (in contrast to Florida), it was surprising to see several districts that did not even have a single write-in vote for primary races. In these and similar cases, these seats were eliminated from being counted as "unopposed," because there was no one running, or there were no votes cast on the ballot for that respective race. The results reported here will overstate the estimates of competition and err on the side of caution. The data utilized here examines the time period immediately prior to and following the years that term limits took effect. It is meant only as a first gauge of the empirical impact of term limits on competition within these two states.

\section{Florida Data and Findings}

Using data provided from Florida state legislative elections in the period 1996-2006, several tests are conducted on the underlying premise of term-limits supporters that restrictions on terms will generate greater degrees of competition. Furthermore, we examine the data to test our competing hypothesis that legislative term limits lead to cyclical periods of lower competition. To test these hypotheses, we obtained the election results from each of the legislative elections from 1996-2006 from the Division of Elections of the Florida Department of State. As the first wave of Florida legislators were term-limited out of office in 2000, this time period provides the initial picture of electoral patterns governed by term limits. ${ }^{2}$ To address possible spuriousness, we examine the data in light of one prominent alternative ground in the influences of partisan redistricting. Using the official returns from the primaries

\footnotetext{
${ }^{2}$ While data from previous elections are available, we did not use it in our analysis as the electoral cycles in Florida during the 1990s were determined by a significant partisan shift from majority Democratic legislature to a majority Republican (Conley 2003).
} 


\section{Table 1. Florida Senators and Representatives Unopposed in Both Primary and General Elections, 1996-2006}

\begin{tabular}{|c|c|c|c|c|c|c|c|c|}
\hline \multirow[b]{3}{*}{ Year } & \multicolumn{4}{|c|}{ House } & \multicolumn{4}{|c|}{ Senate } \\
\hline & \multirow{2}{*}{\multicolumn{2}{|c|}{$\begin{array}{l}\text { Unopposed } \\
\text { Dem Rep }\end{array}$}} & Total & Percent & \multirow{2}{*}{\multicolumn{2}{|c|}{$\begin{array}{l}\text { Unopposed } \\
\text { Dem Rep }\end{array}$}} & Total & Percent \\
\hline & & & Races & Unopposed & & & Races & Unopposed \\
\hline 2006 & 14 & 31 & 120 & $38 \%$ & 2 & 6 & 20 & $40 \%$ \\
\hline 2004 & 17 & 34 & 120 & 43 & 5 & 6 & 22 & 50 \\
\hline 2002 & 11 & 7 & 120 & 15 & 6 & 12 & 40 & 45 \\
\hline 2000 & 8 & 6 & 120 & 12 & 2 & 6 & 21 & 38 \\
\hline 1998 & 14 & 37 & 120 & 43 & 4 & 7 & 21 & 52 \\
\hline 1996 & 21 & 31 & 120 & 43 & 4 & 6 & 21 & 48 \\
\hline Average & 14.2 & 24.3 & 120 & $32 \%$ & 3.8 & 7.2 & 24.2 & $46 \%$ \\
\hline
\end{tabular}

Source: Florida Department of State, Division of Elections (2008).

and general elections, the picture of Florida's electoral health in the era of term limits becomes readily apparent.

Although Florida adopted term limits in 1992, the first class of term-limited legislators did not appear until 2000. Yet the effect of the new limits can be seen almost immediately in the data. Table 1 identifies those Florida House and Senate members who did not face challengers in either their primaries or general elections. ${ }^{3}$ As illustrated in Table 1, and focusing on just the House side, the numbers of unopposed candidates reached stark levels in 1996 and 1998, where just short of half of the legislators were unopposed in their races. It was not until the first group of term-limited legislators was barred from reelection in 2000 that the rates of unopposed legislators declined sharply. Yet this time of increased competition is not sustained. By 2004, the rates are again approaching the initial levels in the table. On the Senate side, the results are more mixed but nonetheless reveal a similar pattern.

The results fit our expectations for rational actors seeking legislative office, especially in the House. Candidates will likely expend the resources needed to win a seat during years when the absence of an incumbent increases the chances of winning (Feddersen, Sened, and Wright 1990). It is often more difficult to face an incumbent, and because term limits can generate open seats in

\footnotetext{
${ }^{3}$ Although all members of the Florida House of Representatives must face the voters every two years, the terms of the Florida senators are set at four years by the Florida Constitution in Section 15 (a), and they are to have staggered elections whereby those from odd-numbered districts will be up for election in the years the numbers of which are multiples of four while even-numbered districts will hold elections in the years which are not multiples of four. However, the Florida Constitution does make an exception for the election next following a reapportionment, where some senators shall be elected for terms of two years when necessary to maintain staggered terms. Thus the 2002 redistricting resolution passed by the Legislature mandated that senators representing odd numbered districts had to stand for election in 2002. This is why most years see a total of half of the seats in the Senate at issue.
} 
predictable patterns, the rational candidate is likely to avoid running for seats with entrenched incumbents. However, this pattern is not uniform, probably for a variety of reasons that include resignations as a result of illness, pursuing other opportunities - all of which points to some legislators leaving before serving the entire allowable eight years. Nonetheless, the pattern is clear for both chambers in that competition sharply increases during 2000 - the first term-limited yearand then quickly becomes noncompetitive in the subsequent election cycles (excepting the 2006 Senate). It is obvious that sustained competition envisioned by some analysts (Will 1992) simply does not appear.

The reduction in competition is unambiguous in the measure of competition used here, and it suggests that a narrow focus on the rate of turnover may miss more subtle trends. Beginning in 2000, the term limits did increase the number of open seats; however, competition did not increase, but rather declined over the rest of the period, so that by 2006, the competitiveness of the elections sharply declined when 14 House Democrats and an astonishing 31 Republicans faced no competition in their election cycles. The data suggest that while term limits may have removed some long-sitting legislators, the replacements were subject to a less competitive environment.

Although less severe in terms of the magnitude of change, the numbers in the Florida Senate reveal that the proportion of legislators who were unopposed for election or reelection mimic the House in that the lowest percentage is found in 2000, the initial year that term limits apply. The results of the 2004 Senate general election are particularly notable, because despite the more populous Senate districts from which a challenger could be drawn, only eleven of the 22 seats up for election fielded any challenger.

Table 1 also indicates a partisan differential in the percentage of Florida House and Senate candidates without opposition in both their primary and general elections. It is easy to verify that Republicans hold clear advantages in both chambers in the proportion of unopposed candidates throughout the entire period. In the House, Republicans average a ten percentage-point lead in unchallenged candidates, while in the Senate, it is a more modest three and one-half percentage difference. Nonetheless, for both chambers, these numbers mean that Republicans on average are at least 50 percent less likely to face opposition throughout their electoral cycle than Democrats. As the magnitude of the Republican benefit is so significant, one may be inclined to attribute the diminished competition to partisan redistricting (Niemi and Jackman 1991). Although this is plausible, such a test is beyond the scope of this study. Instead, it is enough to know that the rise of the Florida Republican party coincides with a distinct partisan advantage in the propensity to be challenged for their legislative seats, and term limits appear to have an effect on this setting.

Because the Florida data are consistent with an electoral effect from term limits that does not equally impact the two major parties, it is important to check whether or not there has been a decline since 2000 in competition within each of the two major parties. Table 2 compares the numbers of candidates 
Table 2. Candidates for Florida House of Representatives and Senate, 2000-6

\begin{tabular}{|c|c|c|c|c|c|c|c|c|}
\hline \multirow[b]{3}{*}{ Year } & \multicolumn{4}{|c|}{ House } & \multicolumn{4}{|c|}{ Senate } \\
\hline & \multicolumn{2}{|c|}{ Primary } & \multicolumn{2}{|c|}{ General } & \multicolumn{2}{|c|}{ Primary } & \multicolumn{2}{|c|}{ General } \\
\hline & $\mathrm{N}$ & Comp & $\mathrm{N}$ & Comp & $\mathrm{N}$ & Comp & $\mathrm{N}$ & Comp \\
\hline 2006 & 195 & .81 & 193 & 1.61 & 32 & 1.6 & 36 & 1.8 \\
\hline 2004 & 175 & .73 & 196 & 1.63 & 26 & .59 & 34 & 1.55 \\
\hline 2002 & 209 & .87 & 256 & 2.13 & 66 & .83 & 63 & 1.58 \\
\hline 2000 & 263 & 1.10 & 217 & 1.81 & 38 & .90 & 42 & 2.0 \\
\hline Average & 210.5 & .88 & 215.5 & 1.80 & 40.5 & 1.56 & 43.8 & 1.73 \\
\hline
\end{tabular}

Source: Florida Department of State, Division of Elections (2008).

across primaries and general elections for the Florida House and Senate since term limits have taken effect, and again the data are consistent with diminishing competition.

Although not as consistent as the data in Table 1, Table 2 reveals a general pattern of declining competition even at the party primary level in the Florida House and Senate elections from 2000 to 2006. While previous research on term limits has used percentage of vote won as an indicator of competitiveness (Sarbaugh-Thompson et al. 2004; Schraufnagel and Halperin 2006), this study focuses specifically on the pool of candidates to assess the empirical magnitude of actual competition for office (see Fett and Ponder 1993; Francis and Kenny 1997; Powell 2000).

To focus specifically on the pool of actual candidates seeking office, we created a competition score that measures the effectiveness of the electoral system in producing candidates for office. It is appropriate for both intraparty competition (in primaries) and interparty competition in general elections. The competition score is a simple calculation created by the ratio of the total number of candidates running for each chamber's seats divided by the total number of potential races in that particular election. The baseline numbers are established by the size of the legislature. In Florida, all 120 House seats are up for election every two years, meaning there are as many as 120 potential races in each of the two major party primaries resulting in a maximum of 240 races in any given election cycle. The general election is limited to 120 possible races after the nominees from the two parties have been chosen.

The resulting calculation works as follows: if Florida had a fully competitive two-party system, then the expected competition score for the primary election should be at a minimum 4.0. This would mean that at least two candidates ran for the legislature in each of the primaries, resulting in a total of 480 candidates vying for the 120 seats, or a ratio of 4.0. The calculation of the competition score in the general election is similar, though the expected ratio for a fully competitive election should be 2.0 based on two candidates for each opening or 
240 persons vying for 120 possible seats. These expectations exclude those potential candidates who run as candidates of third parties or as write-ins.

The data in Table 2 illustrate how little competition Florida has produced in legislative elections, especially in the primaries, because over this period there is little evidence that term limits have increased the competition and instead, show remarkably high amounts of safety. Indeed, data in the House primaries show competition scores declining from a high of 1.10 in 2000 to .81 by 2006. Scores under 1 suggest that many of the races never took place at all and were removed from the ballot, as there was no attempt in either party to challenge any candidate.

Competition appears to be rare, as measured by our competition score, especially in the 2004 elections in the House. For the 2004 House primaries, the competition score of .73 is representative of virtually no competition in many seats. There was so little competition and so many safe seats that 85 candidates, or 71 percent of the seats, did not even draw an opponent in the primary election. This trend continued in the general election, where the competition score only slightly improved to 1.63 . Out of 120 seats in the House, there were 17 Democrats and 34 Republicans (for a total of 51 members) who did not face any opponents either in a primary or a general election.

The safety of incumbents is almost unprecedented in the Florida House, unless one is looking at the Florida Senate. An examination of the competition scores for the Senate primary and general election in 2004 is stark. In that year, the competition scores of .59 in the primary and 1.55 in the general election hide the fact that 19 candidates were unopposed in the primary, while six Republicans and five Democrats did not have any opponents throughout the entire year and took their seat without a vote cast for them.

The data suggest that over this entire period, the candidates from the two major parties were largely safe from internal partisan electoral challenges. The Florida House scores in the general election, while marginally better than the primary scores, still fail to evidence substantial levels of competition. The House competition score in the general election falls from 1.81 in 2000 to 1.61 by 2006 . In sum, term limits have not pushed competition anywhere near the expected score of 2.0 if a larger pool of candidates is the consequence of term limits.

The Republican dominance explanation of declining competition is not evidenced in this data. The competition scores suggest little in the way of competitive elections at either the primary or general level. The primaries, if anything, have slightly less competition. The competition scores for the period reveal an average of fewer than two candidates per race in either the House or the Senate, and this is true no matter if one is looking at primaries or general elections. Although not reported in the table, when combining all elections across the years in both chambers, the mean of these average competition scores is 1.71. Although there is not a strong trend toward diminished competition over the entire period, it is instructive that with the exception of the 2002 Florida House general election, no competition score went up over the score from 2000. 
Table 3. Percent of Races without Challengers in Florida House and Senate, 1996-2006

\begin{tabular}{lllll}
\multicolumn{2}{l}{$\begin{array}{l}\text { Unopposed Primary } \\
\text { House }\end{array}$} & Senate & Unopposed General \\
& & & House & Senate \\
2006 & $67.5 \%$ & $60.0 \%$ & $44.2 \%$ & $40.0 \%$ \\
2004 & 70.8 & 86.4 & 45.8 & 50.0 \\
2002 & 65.8 & 67.5 & 17.5 & 52.5 \\
2000 & 47.5 & 52.4 & 25.8 & 38.1 \\
1998 & 64.2 & 66.7 & 62.5 & 66.7 \\
1996 & 69.2 & 80.1 & 48.3 & 47.6 \\
Average & $64.2 \%$ & $68.9 \%$ & $40.7 \%$ & $49.2 \%$
\end{tabular}

Source: Florida Department of State, Division of Elections (2008).

As the institutional incentives provided by term limits are clearly not the only variables candidates must consider when deciding to run, some variance in the declining pattern is to be expected because of national or even local events, but the general pattern of decline is clear on the face of the data.

What is increasingly clear is that the era of term limits has not resulted in a cycle of competitive elections. Table 3 reports the percentage of House and Senate races that had no opposition in each year. It is further broken down by primary and general election. Recall that Table 1 examined only those candidates who had no challengers in both the primary and general election. Table 3 includes these candidates as well as additional candidates who may have had competition in one election, i.e., the primary, but then had no challengers in the general election, or vice versa. ${ }^{4}$

Table 3 reports the proportion of seats that are unopposed. Consistent with the analysis thus far, the data indicate that the term limits year of 2000 was again pivotal on this measure in that it, without exception, was the election year that had the most races with competition, but nonetheless, these levels were not sustained. Comparing elections before and after term limits, it can be seen that across chambers and across election type, the increase in competition levels mitigates over time. Moreover, there appears to be a higher average propensity for limiting competition in the Senate than in the House in that overall, a higher proportion of Senate candidates are less likely to face challengers than their

\footnotetext{
${ }^{4}$ If a district seat was up for election, they were included in the analysis for that year. Thus all 120 House seats were eligible for inclusion, as were the appropriate Senate seats, and these numbers served as the baseline for the proportion. As for primaries, if at least one candidate for the district seat had a challenger in their own party's primary, the seat was not counted as unopposed. For example, in 2006 district 10 had two Republican candidates and one Democrat vying for the seat. The Democrat candidate was technically "unopposed" in the primary, but the two Republicans were challengers to each other. Thus, the seat was not classified as "unopposed" for this part of the analysis. But consider district 22 in the same year. In the primary, there was one "unopposed" Republican and one "unopposed" Democrat, both of whom met later in the general election. This seat was classified as unopposed in the primary but not in the general election.
} 
House compatriots. Indeed, the most egregious difference occurred in the 2002 general election when the Senate had fully three times the percentage of unopposed seats as the House (52.5 percent to the House's 17.5 percent). Hence, the upper chamber in Florida tends to have less competition for its seats than the lower chamber, whether or not one looks at the primary or the general election.

While having a less competitive Senate is contrary to expectations based on the desirability of the Senate as a more prestigious seat, it is consistent with our rational actor hypothesis. Ultimately, the cost of running for a more populous and more exclusive Senate seat is higher than that of the House. Potential candidates for the Senate are likely further motivated to wait for the inevitable open seat rather than expend the increased resources to compete against an incumbent during the length of the eight-year term. It follows that in general, the more resources required for the seat, the greater the risk, which means that candidates are more likely to account for term limits when strategically assessing when to seek another office.

\section{Contrasting Maine: Data and Findings}

While this research is primarily an assessment of Florida as a case study, in this section we begin to broaden the implications of term limits by considering its effects in an alternative forum unlike Florida. Although term limits in at least half a dozen states have either been repealed or declared legally unsound, term-limit policies continue to remain in force in over a dozen states. Because partisanship is believed to play a dominant role in modern Florida electoral politics, we wanted to look at a state that lacks Florida's pattern of one-party dominance (Conley 2003). Maine presents a window on these broader effects. The legislative elections in both states were subject to term limits after changes in the 1990s. Both the Maine Senate and House members are elected to serve two-year terms, while members of the Florida House serve two-year terms and Florida Senators serve terms of four years. These two states are similar in many respects. Voters in both states adopted limits by wide margins with over twothirds of voters approving. Moreover, Florida and Maine enacted term-limits legislation chronologically very close together in 1992 and 1993, respectively.

Both states share eight-year prohibitions that apply to both chambers in the two states and these limits apply to consecutive terms as opposed to lifetime limits (National Conference of State Legislatures 2005). In both states, upon hitting the limit in one chamber, a legislator may run for election to the other chamber or leave the legislature. Also, chambers elect members from single member districts in both states. Although the years term limits were enacted between the states are similar, the year of impact differs across these two states. The impact on Maine's legislators first took effect in 1996, while the effect did not impact Florida's legislators until 2000. Table 4 compares the years and magnitude of the legislators forced out by the term limits in each state. 
Table 4. Number of Senators and Representatives Term-Limited Out of in Elections, 1996-2006

\begin{tabular}{|c|c|c|c|c|c|c|c|c|}
\hline \multirow{3}{*}{$\begin{array}{l}\text { Year } \\
2006\end{array}$} & \multicolumn{4}{|l|}{ Florida } & \multicolumn{4}{|l|}{ Maine } \\
\hline & \multicolumn{2}{|c|}{ Limited in House } & \multicolumn{2}{|c|}{ Limited in Senate } & \multicolumn{2}{|c|}{ Limited in House } & \multicolumn{2}{|c|}{ Limited in Senate } \\
\hline & $15.8 \%$ & (19) & $12.5 \%$ & (5) & $12.6 \%$ & (19) & $2.9 \%$ & (1) \\
\hline 2004 & 58.3 & (7) & 0 & (0) & 13.9 & (21) & 20 & (7) \\
\hline 2002 & 11.7 & (14) & 30 & (12) & 18.5 & (28) & 22.9 & (8) \\
\hline 2000 & 45.8 & (55) & 27.5 & (11) & 11.3 & (17) & 20 & (7) \\
\hline 1998 & \multicolumn{2}{|c|}{ N/A } & \multicolumn{2}{|c|}{ N/A } & 7.3 & (11) & 2.9 & (1) \\
\hline 1996 & \multicolumn{2}{|c|}{ N/A } & \multicolumn{2}{|c|}{ N/A } & 17.2 & (26) & 11.4 & (4) \\
\hline Average & $32.9 \%$ & (24) & $17.5 \%$ & (7) & $13.5 \%$ & (20) & $13.4 \%$ & (5) \\
\hline
\end{tabular}

Source: Compiled by authors from data at the National Conference of State Legislatures (2008a,b); $\mathrm{N}$ in parentheses.

While there are clear similarities in the adoption of term limits, Maine stands in strong contrast to Florida. There are significant differences between the states, as Maine is less populous than Florida - 1.2 million and 18 million, respectively - and Florida is much more diverse with significant populations of minorities. Indeed, Maine is over 80 percent caucasian (U.S. Department of Commerce 2000). Yet Maine makes an interesting case study to contrast with Florida, because it lacks the stringent partisan dynamics that exist in Florida. Despite a Republican heritage, beginning in the latter half of the twentieth century, Maine has had a balanced partisan division including a significant and active independent voting bloc. Currently, independents outnumber both enrolled Democrats and Republicans and are typically the most pivotal voting bloc in modern elections in the state. This helps to explain why Maine has had two independent governors, James B. Longley in 1974 and Angus S. King, Jr., in 1994.

In contrast, Florida's legislature was dominated by the Democrats until the Republican dominance beginning in the mid-1990s. Maine voters regularly elect candidates from both parties, and independents. Consider that in the 2000 presidential election, Maine voted for Democrat Al Gore for President while electing Republican Senator Olympia Snowe and two Democrats in its two House races. In 2002, Maine reelected Republican Senator Susan Collins, while voting for a Democrat, John Baldacci, as Governor. In 2004, Maine voted strongly for John Kerry while helping the Republicans to significant gains in the legislature. Thus Maine's political system is less polarized than Florida, and allows us to assess whether term limits are as determinative in a sharply less partisan atmosphere.

Despite the clear differences between the size and demographic makeup of both states and the fundamental difference in partisanship, the effect of term limits on Maine appears to be as significant as that in Florida. After the 
Table 5. Number of Maine Senators and Representatives Unopposed in Primary Elections, 1992-2006

\begin{tabular}{|c|c|c|c|c|c|c|c|c|}
\hline \multirow{3}{*}{$\begin{array}{l}\text { Year } \\
2006\end{array}$} & \multicolumn{4}{|c|}{ House } & \multicolumn{4}{|c|}{ Senate } \\
\hline & \multicolumn{2}{|c|}{$\begin{array}{l}\text { Unopposed } \\
\text { Dem Rep }\end{array}$} & \multirow{2}{*}{$\begin{array}{l}\text { Total } \\
\text { Seats } \\
151\end{array}$} & \multirow{2}{*}{$\begin{array}{l}\text { Average \# } \\
\text { Unopposed } \\
139.5\end{array}$} & \multicolumn{2}{|c|}{$\begin{array}{l}\text { Unopposed } \\
\text { Dem Rep }\end{array}$} & \multirow{2}{*}{$\begin{array}{l}\text { Total } \\
\text { Seats } \\
35\end{array}$} & \multirow{2}{*}{$\begin{array}{l}\text { Average \# } \\
\text { Unopposed } \\
32.5\end{array}$} \\
\hline & 140 & 140 & & & 32 & 33 & & \\
\hline 2004 & 136 & 138 & 151 & 137 & 28 & 32 & 35 & 29.5 \\
\hline 2002 & 140 & 126 & 151 & 133 & 27 & 32 & 35 & 29.5 \\
\hline 2000 & 139 & 112 & 151 & 125.5 & 30 & 33 & 35 & 31.5 \\
\hline 1998 & 138 & 125 & 151 & 131 & 30 & 33 & 35 & 31 \\
\hline 1996 & 103 & 89 & 151 & 97 & 10 & 10 & 35 & 10.5 \\
\hline Average & 132.7 & 121.7 & 151 & 127.2 & 26.2 & 28.8 & 35 & 27.5 \\
\hline 1994 & 73 & 71 & 151 & 72 & 3 & 9 & 35 & 0 \\
\hline 1992 & 7 & 9 & 151 & 8 & 4 & 0 & 35 & 26 \\
\hline Average & 40 & 40 & 151 & 40 & 3.5 & 4.5 & 35 & 13 \\
\hline Average 1992-2006 & 109.5 & 101.3 & 151 & 105.4 & 20.5 & 22.75 & 35 & 23.8 \\
\hline
\end{tabular}

Source: Compiled by authors from data at the Maine Department of State, Elections Division (2008); and ICPSR No. 21480.

implementation of term limits, the number of legislators running unopposed for office increased dramatically as illustrated in Table 5. In the two elections prior to redistricting, Maine averaged approximately 58 races unopposed in the House primary. In the years after the implementation of term limits, the House averaged almost 127 unopposed races out of 151 possible contests. In the Maine Senate primaries, out of a possible 35 races, it went from 13 unopposed races to an average of almost 28 contests after the adoption of term limits. Granted, one might question the unequal weighting comprising the averages (two elections prior to term limits and six elections after), but that is not the point. What is important here is the noteworthy consistency of the pattern with that found in Florida: the year of applying term limits (for Maine in 1996) shows the expected rise in opposition and the inevitable decline thereafter. Apparently, reapportionment has as much of an impact on competition as the initial year of term limits, yet as time marches on, the effects fade quickly and substantially.

Interestingly, after eight years of term limits, the Maine data does not show a competitive year with candidates competing for open seats, as we theorize Florida would likely do. After the first group of legislators has been termed out, we would expect a group of candidates to take advantage of the open seats. The absence of this in the Maine data is in part a product of how Maine implemented term limits. Maine staggered the application of term limits so that a large number were not termed out all at once, as can be seen in Table 4. As a result, the method of term-limit implementation appears to have in empirical impact on state primaries, but probably not as much in the general elections. 
Table 6. Number of Maine Senators and Representatives Unopposed in General Elections, 1992-2006

\begin{tabular}{|c|c|c|c|c|c|c|c|c|}
\hline \multirow{3}{*}{$\begin{array}{l}\text { Year } \\
2006\end{array}$} & \multicolumn{4}{|c|}{ House } & \multicolumn{4}{|c|}{ Senate } \\
\hline & \multicolumn{2}{|c|}{$\begin{array}{l}\text { Unopposed } \\
\text { Dem Rep }\end{array}$} & \multirow{2}{*}{$\begin{array}{l}\text { Total } \\
\text { Seats } \\
151\end{array}$} & \multirow{2}{*}{$\begin{array}{l}\text { Average \# } \\
\text { Unopposed } \\
2\end{array}$} & \multicolumn{2}{|c|}{$\begin{array}{l}\text { Unopposed } \\
\text { Dem Rep }\end{array}$} & \multirow{2}{*}{$\begin{array}{l}\text { Total } \\
\text { Seats } \\
35\end{array}$} & \multirow{2}{*}{$\begin{array}{l}\text { Average \# } \\
\text { Unopposed } \\
0\end{array}$} \\
\hline & 70 & 0 & & & 0 & 0 & & \\
\hline 2004 & 0 & 3 & 151 & 1.5 & 1 & 1 & 35 & 1 \\
\hline 2002 & 12 & 7 & 151 & 9.5 & 1 & 3 & 35 & 2 \\
\hline 2000 & 22 & 10 & 151 & 16 & 0 & 1 & 35 & .5 \\
\hline 1998 & 21 & 13 & 151 & 17 & 4 & 1 & 35 & 2.5 \\
\hline 1996 & 8 & 3 & 151 & 5.5 & 2 & 0 & 35 & 1 \\
\hline Average & 22.2 & 6 & 151 & 14.1 & 1.3 & 1 & 35 & 1.2 \\
\hline 1994 & 3 & 2 & 151 & 2.5 & 0 & 0 & 35 & 0 \\
\hline 1992 & 18 & 11 & 151 & 14.5 & 4 & 0 & 35 & 2 \\
\hline Average & 10.5 & 6.5 & 151 & 8.5 & 2 & 0 & 35 & 1 \\
\hline Average 1992-2006 & 19.3 & 6.1 & 151 & 8.6 & 1.5 & .8 & 35 & 1.1 \\
\hline
\end{tabular}

Source: Compiled by authors from data at the Maine Department of State, Elections Division (2008); and ICPSR No. 21480.

Table 6 reports the number of Maine legislators who are unopposed in general elections. It can be seen that here, Maine does not show as stark a pattern as the primaries. While there is a general trend of decreasing competitiveness, Maine does not demonstrate the same stark pattern of decline across the eight-year term as shown in Table 5 . We theorize that this is largely the result of Maine's partisan diversity. Within the scope of the primaries, the large number of unopposed candidates is noticeable, and the pattern mimics Florida. The primary candidates are largely making the same interested calculation and waiting for the open seat in both Florida and Maine. However, in the general election, Maine's propensity for multiple small parties, numerous write-in candidates who garner relatively few votes and the presence of so many independent voters is likely keeping the raw numbers of unopposed candidates smaller in absolute terms, as independent and small-party candidates form a significant pool from which to draw competition despite the term limits.

In the end, Maine's broader political diversity actually helps direct the power of term limits to create opportunities for alternative parties to at least compete, if not win. Florida's dominant two-party system cannot produce the same results. Nonetheless, the effect of term limits within the parties themselves reveals a generalized pattern of lowered competition. This is perhaps the most significant aspect of term limits, because Maine, like Florida, tends to still elect officials from the two major parties. The data in Maine suggest that, in the absence of a two-party system, a term-limits regime might have a more powerful effect in driving competition based on electoral cycles. 


\section{Conclusion}

This study explores the contradiction of declining competition in the era of term limits. The modern trend in legislative elections is the stark decline in competition for the seats on many fronts. This trend seems largely counterintuitive; as studies have shown that state legislators generally are largely satisfied with their careers in the legislature (Williams 1997), thereby making the job one that should draw many qualified candidates. Yet there appears to be very little competition for the seats themselves. If the seats are as desirable as surveys suggest, then it follows there should be many people seeking the seats in competitive elections. The evidence nevertheless indicates that not only are most legislative elections noncompetitive, the lack of electoral competition is actually worsening.

The data are clear that there are few challengers to incumbents despite the fact that legislative terms are limited. Thus, it is difficult to avoid pointing to the gerrymandering revolution of the 1990s as one culprit, because it is no longer a secret that the added technological precision and sophistication of those who draw the legislative districts are such that politicians now control the distribution of the voting electorate to a large extent. The lack of competition between and within the two parties is likely attributable to the success of incumbents and their party's legislative leaders in raising money, as well as the strategic allocation of legislative resources to help in each member's reelection efforts. The data show that the dearth of viable third-party alternatives and the inability of the Democrats to field candidates across the state have contributed as well in Florida.

Nonetheless, there is also a structural component to this trend. Competition is in decline because of the effective date of the implementation of term limits in Florida and in Maine. It is increasingly clear that potential challengers for a seat will likely wait for the seat to open, rather than compete against a popular and well-funded sitting legislator. Ironically, rather than hurting incumbents, term limits, at least during the length of the term, are likely to keep an incumbent safe. While the effects of term limits on the Florida legislature are still being studied and understood, the early trends suggest that the competitive impact may be significant. Initially, term limits forced substantial turnover in the legislature by forcing out members in 2000 . Since that time, however, the unmistakable pattern uncovered in this analysis demonstrates that legislators have faced little opposition and have easily won reelection.

Research on competition has almost exclusively focused on the percentage of the vote won, as the best indicator of whether a race is a viable political contest, or alternatively on the net turnover in a legislative body (SarbaughThompson et al. 2004; Schraufnagel and Halperin 2006). In this research, we assess an indicator based specifically on the actual pool of candidates for office to empirically gauge the tangible competition for office. While the earlier 
indicators are useful, they do not adequately assess the more basic question of whether term limits are actually drawing more candidates into the races. This is a central issue, as scholars and proponents of term limits have made the assertion that a larger pool of experienced candidates should be available and able to challenge for seats as a result of term limits (Fett and Ponder 1993; Francis and Kenny 1997; Powell 2000).

Accurately measuring the pool of electoral challengers for legislative seats is a public policy necessity for anyone who wants to assess the electoral health and competitiveness in state legislative races. This has been the focus of the current research, and it tends to supplement the more widely used measures of competition. Indeed, the measure used here helps future researchers and legislative practitioners better predict the direction and impact of legislative partisan and secular changes attributable to term limits. Moreover, party leaders in states considering adopting limits should keep in mind the differential impact that implementing the limits can have on both interparty and intraparty competition.

While judging the magnitude of a candidate's victory speaks to individual race competitiveness, it may lead to a premature dismissal of the effects of term limits, especially in the first few years when new candidates are just beginning to engage more actively and play a more significant role within the electoral system. The new measure offered here which calculates a ratio based on the numbers of candidates running for each seat, represents a reasonable assessment of the supposition that term limits will open up the political system to a larger pool of candidates. The absence of these candidates, as shown both in the Florida and Maine data, suggests that term limits are not drawing the candidates, and as a result, are unlikely to create a more viable competitive environment for politics in the future. If this pattern continues, then the fundamental assertion that term limits will create a more democratic, open, and active electoral environment populated by citizen legislators, will be, and will continue to be, almost entirely false.

Even beyond this study, there may be additional consequences to term limits that will become more evident. By restricting the time an elected official can serve in a particular office, term limits will move well-known and well-funded candidates through different elected state and local positions, discouraging the entrance of new candidates into the political system. Consider that a termlimited member of the Florida or Maine legislature would make a daunting opponent in most local elections, and many statewide ones as well. Florida, Maine and other states may have, in fact, created mobile incumbents who want to continue engaging in their chosen occupation, namely, politics. Facing termination of their contracts because of term limits, and open to the prospect of wishing to remain employed in their field, the circumstances require they look for future employers who are open to new employees, again because of term limits. This appears to be a system more akin to musical chairs than open, free, and competitive elections. 
Ultimately, proponents of term limits may have to face the unhappy truth that although term limits may have visceral appeal in trying to curb career politicians, the reality as illustrated by the data presented in this article indicate a large gap between the paradigmatic representative democracy taught in schools and the empirical reality embodied in state legislatures. The results in Florida illustrate that legislative seats in both chambers are increasingly noncompetitive, and are in an environment of majority-party control over institutionalized legislative procedures. It might be worth asking if the interests of citizens can be effectively organized and attended to within the current environment.

With such diverse issues facing the states from concerns related to economics, health care, education, and transportation, to those of environmental protection and resource management, the reliance on the desire for a part-time citizen legislature may be in need of renewed scrutiny. Perhaps the experience of mobile politician-employees that is gained over time will counter the detrimental effects of citizen-legislators who lack institutional memory, but this is left to other researchers to gauge and examine.

\title{
Appendix
}

\section{Cases}

Baker v. Carr, 369 U.S. 186 (1962)

Reynolds v. Sims, 377 U.S. 533 (1964)

\begin{abstract}
About the Authors
Kevin M. Wagner is Assistant Professor of Political Science and Associate Director of the Jack Miller Forum at Florida Atlantic University. Dr. Wagner holds a Ph.D. in Political Science and a J.D. from the University of Florida, and teaches in the fields of American Politics and Political Behavior. He is the author of work on both national and state politics and the evolving role of the Internet in national and state campaigns.

Eric Prier is Associate Professor of Political Science at Florida Atlantic University. In recent publications and presentations at national and international conferences, Professor Prier's current research agenda focuses on the social and institutional barriers to enhancing effectiveness and accountability in public procurement. Considered an empirical theorist with a background in survey research and political methodology, he has also published scholarly work on legislative representation and democratic issues. Dr. Prier received his undergraduate degree from The University of Florida in Political Science and his graduate degree from Florida State University.
\end{abstract}




\section{References}

Bernstein, Robert A., and Anita Chadha. 2003. "The Effects of Term Limits on Representation: Why So Few Women?" In The Test of Time: Coping with Legislative Term Limits, edited by Rick Farmer, John David Rausch, Jr., and John C. Green. Lanham, MD: Lexington Books. 147-158.

Bianco, William T. 1984. "Strategic Decisions on Candidacy in U.S. Congressional Districts.” Legislative Studies Quarterly 9 (1): 352-364.

Boeckelman, Keith A. 1993. "Term Limitation, Responsiveness, and the Public Interest." Polity 26 (2): 189-205.

Bowser, Jennifer Drage, Keon S. Chi, and Thomas H. Little. 2006. Coping with Term Limits: A Practical Guide. Denver, CO: National Conference of State Legislatures. Accessed on October 14, 2008. Available online at http://house. louisiana.gov/H_Reps/TermsCmteDocs/NCSL-term\%20limits\%20final.pdf

Cain, Bruce E., and Marc A. Levin. 1999. "Term Limits." Annual Review of Political Science 2 (1): 163-188.

Capell, Elizabeth A. 1996. "The Impact of Term Limits on the California Legislature: An Interest Group Perspective." In Legislative Term Limits: Public Choice Perspectives, edited by Bernard Grofman. Boston, MA: Kluwer Academic Publishers. 67-85.

Caress, Stanley M. 1999. "The Influence of Term Limits on the Electoral Success of Women." Women and Politics 20 (3): 45-63.

Carey, John M., Richard G. Niemi, and Lynda W. Powell. 1998. "The Effects of Term Limits on State Legislatures." Legislative Studies Quarterly 23 (2): 271-300.

2000. Term Limits in State Legislatures. Ann Arbor, MI: University of Michigan Press.

Carsey, Thomas M., William D. Berry, Richard G. Niemi, Lynda W. Powell, and JAMES M. SNYDER. 2003. "State Legislative Election Returns, 1967-2003." ICPSR No. 21480 (Release Version 4). Accessed on October 14, 2008. Available online at http://dx.doi.org/10.3886/ICPSR21480

Carsey, Thomas M., and James P. Nelson. 2008. "Political Parties in Florida." In Government and Politics in Florida, 3rd edition, edited by J. Edwin Benton. Gainesville, FL: University Press of Florida. 124-146.

Conley, Richard S. 2003. Florida 2002 Elections Update. Boston, MA: Pearson Custom Publishing. 
Cox, Gary W. 1996. "Is the Single Nontransferable Vote Superproportional? Evidence from Japan and Taiwan." American Journal of Political Science 40 (3): 740-755.

Date, Shirish V. 2006. "Term Limit Activist May Be on Education Board 9 Years." Palm Beach Post. December 5, A8.

Dauer, Manning J. 1984. Florida Politics and Government. Gainesville, FL: University Press of Florida.

Delli Carpini, Michael X., and Scott Keeter. 1996. What Americans Know About Politics and Why It Matters. New Haven: Yale University Press.

Depalo, Kathryn. 2006. State Legislative Term Limits and the Law of Unintended Consequences: An Examination of Member Behavior, Power Structure and Legislative Organization in Florida. Unpublished dissertation in partial fulfillment of the requirements for the Ph.D. degree, Florida International University.

Doron, Gideon, and Michael Harris. 2001. Term Limits. Lanham, MD: Lexington Books.

Farmer, Rick, John David Rausch, Jr., and John C. Green. 2003. The Test of Time: Coping with Legislative Term Limits. Lanham, MD: Lexington Books.

Feddersen, Timothy J., Itai Sened, and Stephen G. Wright. 1990. "Rational Voting and Candidate Entry under Plurality Rule." American Journal of Political Science 34 (4): 1005-1016.

Fett, Patrick J., and Daniel E. Ponder. 1993. "Congressional Term Limits, State Legislative Term Limits and Congressional Turnover: A Theory of Change." PS: Political Science and Politics 26 (2): 211-216.

Florida Department of State, Division of Elections. 2008. "Election Results." Accessed on October 15, 2008. Available online at http://election.dos. state.fl.us/elections/resultsarchive/Index.asp

Francis, Wayne L., and Lawrence W. Kenny. 1997. "Equilibrium Projections of the Consequences of Term Limits upon Expected Tenure, Institutional Turnover, and Membership Experience." Journal of Politics 59 (1): 240-252.

Fund, John H. 1992. "Term Limitation: An Idea Whose Time Has Come." In Limiting Legislative Terms, edited by Gerald Benjamin and Michael J. Malbin. Washington, DC: CQ Press. 6-8.

Jacobson, Gary C., and Samuel Kernell. 1983. Strategy and Choice in Congressional Elections. New Haven: Yale University Press.

Kurtz, Karl T., Bruce Cain, and Richard G. Niemi. 2007. Institutional Change in American Politics: The Case of Term Limits. Ann Arbor: University of Michigan Press. 
MacManus, Susan A. 1994. "Women in State Legislative Office." Political Chronicle 6 (1): 10-18.

Maine Department of State, Elections Division. 2008. "Election Results." Accessed on October 15, 2008. Available online at http://maine.gov/sos/cec/elec/ prior1st.htm

Mann, Thomas E., and Raymond E. Wolfinger. 1980. "Candidates and Parties in Congressional Elections." American Political Science Review 74 (3): 617-632.

Mayton, William T. 1999. "Direct Democracy, Federalism \& the Guarantee Clause." The Green Bag 2 (Spring): 269-277.

Mitchell, Cleta Deatherage. 1991. "Limiting Congressional Terms: A Return to Fundamental Democracy." Journal of Law and Politics 7 (Summer): 733-746.

Moncrief, Gary F., and Joel A. Thompson. 2001. "On the Outside Looking In: Lobbyists' Perspectives on the Effects of State Legislative Term Limits." State Politics and Policy Quarterly 1 (4): 394-411.

National Conference of State Legislatures (NCSL). 2005. "Full- and PartTime Legislatures, October." NCSL. Accessed on May 1, 2006. Available online at http://www.ncsl.org/programs/press/2004/backgrounder_fullandpart.htm

. 2006. "The Term Limited States, February." NCSL. Accessed on October 14, 2008. Available online at http:/www.ncsl.org/programs/legman/about/ states.htm

. 2008a. "Members Termed Out." NCSL. Accessed on October 15, 2008. Available online at http://www.ncsl.org/programs/legismgt/about/termedout. htm

2008b. "Term Limits: Legislative Term Limits Overview." NCSL. Accessed on October 14, 2008. Available online at http:/www.ncsl.org/programs/ legismgt/ABOUT/termlimit.htm

Niemi, Richard G., and Simon Jackman. 1991. "Bias and Responsiveness in State Legislative Redistricting." Legislative Studies Quarterly 16 (2): 183-202.

Olson, DAVID J. 1992. "Term Limits Fail in Washington: The 1991 Battleground." In Limiting Legislative Terms, edited by Gerald Benjamin and Michael J. Malbin. Washington, DC: CQ Press. 65-96.

Osborne, Martin J., and Al Slivinski. 1996. "A Model of Political Competition with Citizen-Candidates." The Quarterly Journal of Economics 111 (1): 65-96. 
Parker, Suzanne, and Terri L. Towner. 2008. "Political Culture and Political Attitudes in Florida." In Government and Politics in Florida, 3rd edition, edited by J. Edwin Benton. Gainesville, FL: University Press of Florida. 124-146.

Peery, George. 1999. "Time Line of Term Limits." In State and Local Government, 1999-2000, edited by Thad L. Beyle. Washington, DC: CQ Press. 121-124.

Phelps, John B. 2002. The Florida House of Representatives Handbook. Tallahassee, FL: Office of the Clerk of the House of Representatives.

Powell, Richard J. 2000. "The Impact of Term Limits on the Candidacy Decisions of State Legislators in U.S. House Elections." Legislative Studies Quarterly 25 (4): 645-661.

. 2003. "The Unintended Effects of Term Limits on the Career Paths of State Legislators." In The Test of Time: Coping with Legislative Term Limits, edited by Rick Farmer, John David Rausch, Jr., and John C. Green. Lanham, MD: Lexington Books. 133-146.

Price, Hugh Douglas. 1962. "Florida: Politics and the Pork Choppers." In The Politics of Reapportionment, edited by Malcolm E. Jewell. New York: Atherton Press. 81-97.

PRIER, ERIC. 2003. The Myth of Representation and the Florida Legislature: A House of Competing Loyalties. Gainesville, FL: University of Florida Press.

Rausch, John David, JR. 1996. "The Politics of Term Limitations." In Constitutional Politics in the States: Contemporary Controversies and Historical Patterns, edited by G. Alan Tarr. Westport, CT: Greenwood Press. 98-127.

1998. "Legislative Term Limits and Electoral Competition in Oklahoma: A Preliminary Assessment." Oklahoma Politics 7 (October): 39-58.

Rosenthal, Alan. 1992. "The Effects of Term Limits on Legislatures: A Comment." In Limiting Legislative Terms, edited by Gerald Benjamin and Michael J. Malbin. Washington, DC: CQ Press. 205-208.

Sarbaugh-Thompson, Marjorie, Lyke Thompson, Charles D. Elder, John Strate, and Richard C. Elling. 2004. The Political and Institutional Effects of Term Limits. New York: Palgrave MacMillan.

Schraufnagel, Scot, and Karen Halperin. 2006. "Term Limits, Electoral Competition, and Demographic Change: The Case of Florida." State Politics and Policy Quarterly 6 (4): 448-462. 
Thompson, Joel A., and Gary F. Moncrief. 1993. "The Implications of Term Limits for Women and Minorities: Some Evidence from the States." Social Science Quarterly 74 (2): 300-309.

U.S. Department of Commerce. 2000. Statistical Abstract of the United States 2000. Washington DC: Government Printing Office, Bureau of Census.

Wagner, Kevin. 2005. Image, Authority and Change: Reconstructing Representation in the Modern Era. Unpublished dissertation in partial fulfillment of the requirements for the Ph.D. degree, University of Florida.

Wagner, Kevin, and Eric Prier. 2008. "The Legislature and the Legislative Process in Florida." In Government and Politics in Florida, 3rd edition, edited by J. Edwin Benton. Gainesville, FL: University Press of Florida. 124-146.

Will, George F. 1992. Restoration: Congress, Term Limits and the Recovery of Deliberative Democracy. New York: The Free Press.

Williams, Elizabeth G. 1997. The Impact of Increased Female Representation in U.S. State Legislatures. Unpublished dissertation in partial fulfillment of the requirements for the Ph.D. degree, University of Florida. 